塩酸酸性塩化金酸浴による電析金膜の

電子顕微鏡観察

\author{
田辺良美* ・釜 崎 清 治*

\section{Electron Microscopic Examination of Au Films Electrodeposited from Hydrochloric Auric Chloride Baths} \\ Yoshimi TANABE and Seiji KAMASAKI
}

\begin{abstract}
The effects of hydrochloric acid on Au films, which had been electrodeposited on Fe substrate from hydrochloric auric chloride baths, were examined by electron diffraction and direct electron microscopic observation.
\end{abstract}

The following results were obtained :

(1) The coherencies between the Au plate crystals and Fe substrate were the same as the results in the previous paper.

(2) The growth rate of Au films was accelerated by addition of hydrochloric acid to the auric chloride bath.

(3) The addition of hydrochloric acid was effective in cleaning of Fe substrate, owing to its removing action of oxide films, etc. on its surface. Accordingly, the Au films electrodeposited from the bath, containing $20 \mathrm{cc} \mathrm{HCl} / 100 \mathrm{cc} \mathrm{HAu} \mathrm{Cl}_{4}$, consisted of good single crystals, and the continuity of the film was also improved.

\section{1. 緒言}

純鉄面上に塩酸酸性塩化金酸浴を用いて金を電析した 場合，金膜は初期析出微小粒子，島状構造そして網目状 構造へ之順次成長して金板状晶が完成され，さらに十分 な電析を行なった金膜には，板状晶との密着性のよくな い針状晶あるいは樹枝状晶が板状晶上に成長することを 報告した ${ }^{1), 2 》 。 ~}$

本報では既報のメッキ浴にさらに濃塩酸を添加し，低 $\mathrm{pH}$ 浴による金膜の初期析出状態拉よび単結晶性などに ついて, 金膜の電子線回折と電子顕微鏡直接観察を行な って検討した結果を報告する。

\section{2. 実験方法}

素地金属として純鉄単結晶 (001) および多結晶圧延板 の完全焼ナマシ材を使用した。これをメッキ前処理とし て Jacquet 液で電解研摩を行ない, 水, アルコールにて すばやく洗浄後, フレオンガススプレーで速乾した。メ ッキ浴組成およびメッキ条件を第 1 表に示した。陽極に は炭素板を使用して, 浴電圧 3 Vで電析を行なった。メ ッキにさいしては, 析出初期段階に金の置換析出が電析

* 東京都立大学工学部(東京都世田谷区梁沢2-1-1) Fac. of Tech., Tokyo Metropolitan Univ.
と同時に生ずるのをなるべく避けるため，陰極をメッキ 液に侵入させると同時に通電するようにし，また陰極を メッキ液から引き抜いて電析を終了させ, すばやく水, アルコールで洗浄し乾燥した。このため最初にメッキ液 に入る陰極部分と最後に入る部分では, 金膜の成長に若 干の差が生じることが考えられるので, 電顕試料はすべ て素地鉄の中央部分に析出成長した金膜を使用すること にした。メッキ後, 金膜支持のためにカーボン蒸着を行 ない,これを0.2〜 $5 \%$ ナイタル中に浸セキして金膜を

第1表メッキ浴組成およびメッキ条件

\begin{tabular}{c|c|c|c}
\hline メッキ液名 & $\mathrm{HAuCl}_{4}(\mathrm{wt} \%)$ & $\mathrm{HCl}(\mathrm{cc} / 100 \mathrm{cc})$ & $\mathrm{pH}$ \\
\hline A & 0.15 & 0 & 2.2 \\
B & " & 0.2 & 1.6 \\
C & " & 0.8 & 1.1 \\
D & " & 2 & 0.7 \\
E & " & 5 & 0.3 \\
F & " & 20 & $<0.3$ \\
G & & & $\ll 0.3$ \\
\hline \hline
\end{tabular}

陽 極; 炭素板
浴 電 圧; $3 \mathrm{~V}$
浴 温; 室温
カクハン； 50 r.p.m（マグネット・スターラー）


素地鉄からハク離し，アルコール中でマイクロタッシュ 上にすくいとって電子顕徽鏡の直接観察之電子線同折を 行なった。多結晶素地上の金膜の電子線回折には視野制 限回折法を用い，それぞれの素地結晶粒上の金膜からの 回折像を得た。

\section{3. 実験結果および考察}

\section{3-1 金膜の電子楾回析}

第 2 表はメッキ液 $\mathrm{A} \sim \mathrm{G} て ゙ 0.5 \mathrm{~s} \sim 5 \mathrm{~s}$ 電析して得た 金膜の比較的低指数方位に成長したものの, 電子線回折 結果をるとめたものである。表中第 2 欄の時間は電析時 間の経過を示したるのであり，回折像結果欄中の矢印は 金膜回折像の推移を示している。すなわちメッキ夜 Aの 場合， $0.5 \mathrm{~s}$ 電析した 金膜は結晶性ではあるが，素地鉄 と一定の整合関係が成立していないことを示すデバイ・ シェラー回折環を与えた。メッキの進行ととるに金膜は 素地鉄々整合関係をもつようになり，回折像にはNパタ ーンが観察されるようになる。メッキ液Aの場合には, メッキ時間の経過とともに回折像中の回折環の強度は相 対的に弱くなり，金膜の成長にしたがって一定方位をも たなかった初期析出粒子が再配列を起こし，素地鉄との 整合性を增したことを示している。しかし板状晶完成後 むなお Nバターンととるに回折環が観察され，金膜中に 板状晶と方位を異にする粒子が存在することを示してい た。メッキ液がB，Cなどではィッキ時間の経過による 回折像の変化は, メッキ液 $\mathrm{A}$ の場合と同様の傾向を示し た。しかしメッキ液が $\mathrm{B} ， \mathrm{C} ， \cdots \cdots \mathrm{G}$ と低 $\mathrm{pH}$ ，すなわ ら塩酸添加量が増加するにしたがって，0.5 s の電析に おいても回折像中での回折環の強度は弱くなり，Nパタ ーンが顕著に観察されるようになった。そしてメッキ液 $\mathrm{G} て ゙ は ， 0.5 \mathrm{~s}$ 電析した金膜の回折像にはNパターンだ けが観察されメッキ時間の経過にしたがい板状晶が成 長した過程でもNパターンのみが観察された。このこと は塩酸の添加によって析出初期段階に, 素地鉄格子の方

第 2 表 初期電析低指数方位金膜か.らの電子線回折像

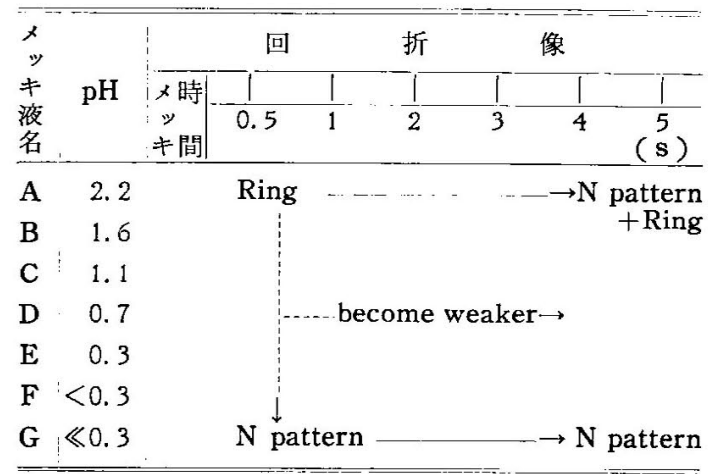

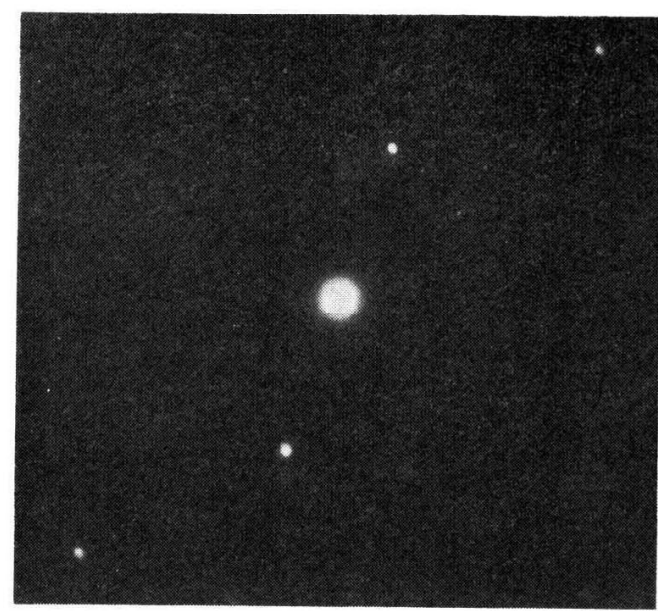

写真1 純鉄単結晶 (001) 上にメッキ液Fで $30 \mathrm{~s}$ 電析して得た金膜の電子線回折像

位配列の影響を受けた単結晶性のよい膜が生成すること を示している。

写真 1 は純鉄単結晶 (001) 上にメッキ液 Fで30 s 電 析して得た金膜の電子線回折像である。この回折像忹金 板状晶からの晶帯軸 [001] のNパターンを与えて特り， 素地鉄面が（001）面であることから，素地鉄と金板状 晶の間には (001) Fe// (001) Au なる整合関俰が成立 していることがわかる。メッキ液 $\mathrm{A} \sim \mathrm{G}$ で (001) Fe 面 上に電析して得た金板状晶の電子線回折を行ない検討し た結果，金膜はいずれも晶帯軸 [001] の Nパターンを 生じ,メッキ液 $\mathrm{A} \sim \mathrm{G}$ の金膜に関して上記の関係が成立 していた。この結果は先の報告】で得た素地鉄と金膜の 間に存在した整合関係が成立していることを示してい る。

鉄の（001）面に金の（001）面が平行に成長する場 合, もっともミスフィットが小さい結晶の方位関係は， 前報1)で報告したよらに鉄の [110]方向と金の [010] 方向を一致させた [110] $\mathrm{Fe} / /[010] \mathrm{Au}$ といら関係で, このときのミスフィットは[100] $\mathrm{Fe}$ と[110] $\mathrm{Au}$ 打よ び [010] Fe と[110] Au について, ともに約0.628\% である。また（110） Fe//(110) Au の場合の方位関係は [001] Fe//[110]Auであり，このときのミスフィットは $[001] \mathrm{Fe},[1110] \mathrm{Au} K$ 対 Lて約 $0.628 \%$ ，[110] Fe, [001]Auに対して約0.617\%となっている。

素地鉄に多結晶を使用した場合，それぞれの素地鉄結 晶粒方位の影響を受けて成立して括り，高指数方位に成 長した金膜も得られた。こうした高指数方位金膜はメッ キ液 $\mathrm{F} ， \mathrm{G}$ などの塩酸涯加量の多い浴からのものでは, 低指数方位金膜と同様，回折像中にNパターンのみが観 察されるものが多く，単結晶性の向上がみからた。しか 
し強度は弱いとはいうむのの，回折環が共存し ている金膜もあった。

素地鉄結晶が高指数方位をもつときの金膜と の整合関係については不明であるが，亡゙のよう な関係が成立したとしても，素地鉄と金とのミ スフィットは (001) Fe//(001) Au, (110) Fell (110)Auなどの関係に比べると大きいるのであ ろう。またミスフィットを考えるとき，素地鉄 面および金膜面上でのいろいろな方向について 検討する必要があり複雑である。高指数方位に 関する整合関係をこのようなミスフィットの大 きさを1つの目安にして考えてみると, (001),

(110) 面のような低指数方位の 場合にみられ た，同一指数面が互いに平行になるといった単 純な関係でなく，同一指数素地面上に種々の方 位の金膜が成長するといらような複雑な関係が 存在することが予想される。電子線回折の結果 を考えあわせると，塩酸添加が高指数方位金膜 の単結晶性向上に効果的であるとはいえ，目的 とする高指数方位の単結晶金膜を鉄面上に生成 することはたいへん困難な問題であろう。

ところで高指数方位金膜からの回折像のなか で回折噮の観察されるものは，2 種類以上のN パターンが共存しているもの，あるいは実際の 成長方位が回折像中の $\mathrm{N}$ パターンが示唆する方 位から数度傾いた金膜がほとんどであること が，金膜傾斜実験の結果わかった。このこと は, 高指数方位の単結晶膜を得る条件の1つと して，素地鉄面を目的指数面に正確に切り出し て使用することの必要性を示唆するるのである 50

\section{3-2 金膜の電子顥微鏡筧察}

写真 2，3は純鉄多結晶上にメッキ液 Dとメ ッ液 $\mathrm{G}$ で $0.5 \mathrm{~s}$ 電析して得られた金膜の電

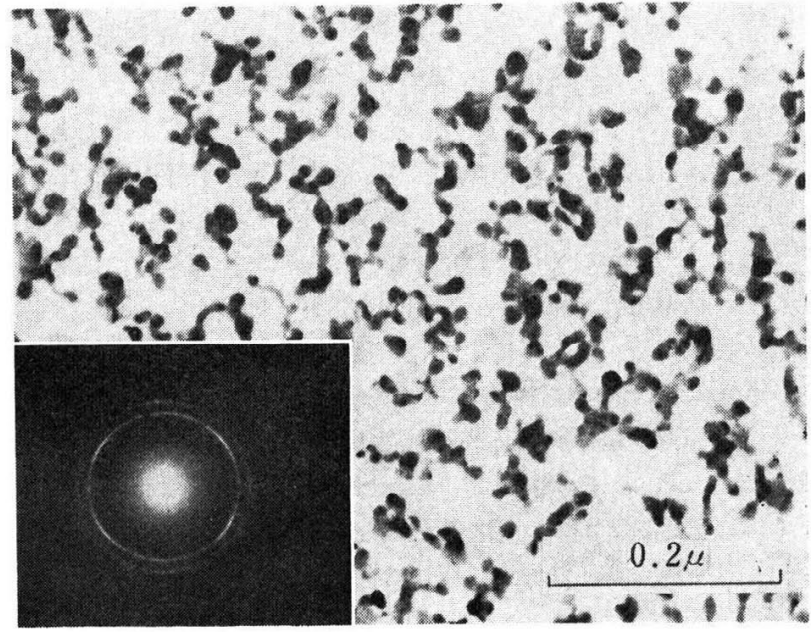

写真 2 純鉄多結晶上にメッキ液Dで0.5s 䉓析して得た 金膜の透過電子顕微鏡像と電子線回折像

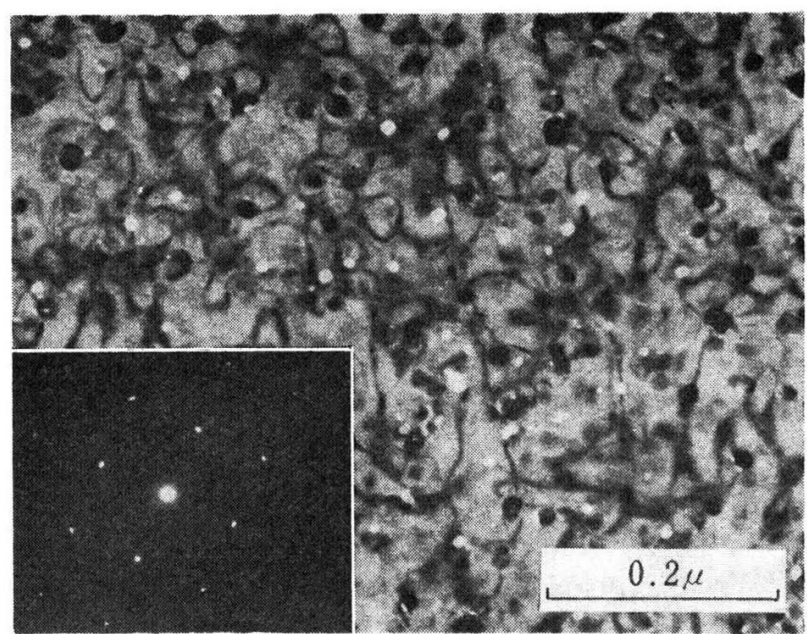

写真 3 純鉄多結晶上にメッキ液 Gで0.5s電析して得た 金膜の透過電子率微鏡像の電子線回折像

このことはメッキ液中の塩酸添加量の増加にしたがっ て，金枚状晶の初期析出成長速度が大となることを示し ている。回折像は第 2 表に示したよらに,メッキ液Dで は回折環と (111) 回折環上に強度の強い部分が 観察さ れるだけでNパターンは観察されないのに対して, メッ キ液 Gでは晶帯軸 [001] の Nバターンがはっきりと観 祭され，塩酸添加により初期析出金膜の単結晶珄はよく なっている。したがって第 2 表および写真 2，3の結果 ををとめると，初期析出金膜は塩酸添加により金膜の成 長速度が促進され，乙かも単結晶珄が良くなるという結 果が得られる。しかし気相からの結晶成長の場合, エピ タキシー温度以上の実験で蒸着膜の単結晶性と蒸者速度

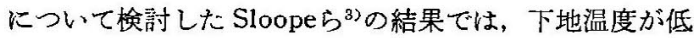

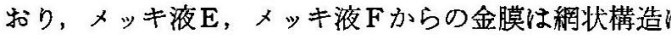
近い搆造をしていて，板状晶は完成されていなかった。 
い場合には蒸着速度の遅いものほど単結晶性がすぐれて いた。

電解研摩して得た素地鉄表面の反射電子線回折像は, 素地鉄の回折像を与えていたが，その研摩面作製過程か ら考えて, 素地上には電子線回折像に寄与しない程度の 異質皮膜層の存在が考えられる。塩類溶液からの結晶成 長では前報》において述べたように，常温において電析 した金膜は素地鉄と結晶学的関連性をもっていることを 示し, 塩類溶液からの電析のさい, 素地鉄表面の状態が $10^{-5} \mathrm{mmHg}$ 程度の真空中に括汀る蒸着の場合の, エピ タキシー温度に保たれた基質表面の状態と類似性を持つ と考えられる。したがって本実験の場合にも, 塩酸添加 によって素地鉄表面の状態に変化がないものとすれば, 成長速度と膜の単結晶性との間には Sloopeら ${ }^{3)}$ の結果が あてはまるはずである。しかし前述の結果はこれと逆の 結果を与えているが, 塩酸添加量の变化に注目し, 初期 析出段階での金の置換析出する可能性についても検討す る必要がある。

塩類溶液, 気相を問わず基質上への結晶成長の場合, 基質表面の清浄度は成長層の単結晶性への重要な因子の 1 つであり, 清浄面に形成された初期析出成長核は, adatom の結晶化による成長にしたがって基質結晶の格 子ェネルギーの影響をうけるようになる。したがって素 地鉄面上の酸化皮膜層なぞの存在は, 初期析出金膜と素 地鉄との結晶学的関係に複雑な影響を与兄, 金膜の内部 構造にも好ましくない結果をもたらすであろら。塩酸の 添加は, こうした酸化皮膜層などの除去作用をもってい る。

写真 3 の電顕像中のリボン状の黒いコントラストは, 試料のベンドュンターで大きさ80〜250 $\AA$ の円形の黒い コントラストは金亜結晶粒であり，板状晶中にはその他 の回折コントラストはほとんど観察されない。井野ら の蒸着膜に関する実験によると, $10^{-7} \sim 10^{-9} \mathrm{mmHg}$ とい う超高真空にして素地表面の脱ガスを行なって清浄化を 行なった場合に, 写真3のような回折コントラストの少

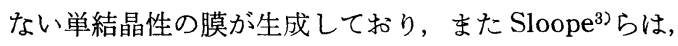
基質の予備加熱をして表面の清浄化をはかることが有効 であると報告している。写真 3 の電顕像は井野, Sloope らの結果のように, 生成した金膜が比較的清浄な素地上 に成長したものであることを示し, 塩酸の添加により素 地表面の酸化物などが破壊除去されることを裏づけてい る。
またメッキ液 $\mathrm{G} に$ 相当する塩酸酸性塩化金酸浴に鉄を 浸セキして得た初期析出置換金膜の電子線回折の結果, 塩酸による酸化皮膜などの除去により, 単結晶性の $\mathrm{N} ハ ゚$ ターンが得られた。したがって電析のときに金の置換析 出がたとえ生じたとしても, 塩酸酸性浴で $\mathrm{pH} \ll 0.3 の よ$ らなメッキ浴では析出初期段階の金膜の単結晶性には大 きな影響をもたないことがわかった。

以上のことから，塩酸添加による金膜単結晶性の向上 には，塩酸による酸化皮膜などの除去といら素地表面の 清浄化が大さく寄与しているすのと思われる。また写真 3の電顕像からもわかるように, 金膜の連続性といら点 に関しても塩酸の添加が有効であることがわかった。

\section{4. 結 論}

種々 $\mathrm{pH}$ に調整した塩酸酸性塩化金酸浴から，鉄面上 に電析して得た初期析出金膜の電子線回析々電子顕微鏡 観察を行ない塩酸添加の影響, とくに金膜の単結晶性へ の効果を中心に検討しつぎの結果を得た。

(1) $\mathrm{pH} \ll 0.3 \sim \mathrm{pH} 2.2$ の塩酸酸性塩化金酸浴からの金 膜と素地鉄との整合関係は，前報1 と同様でありつぎの ようであった。

$$
\begin{aligned}
& \left.\begin{array}{l}
(001) \mathrm{Fe} / /(001) \mathrm{Au} \\
{[110] \mathrm{Fe} / /[010] \mathrm{Au}}
\end{array}\right\} \\
& \text { (110) } \mathrm{Fe} / /(110) \mathrm{Au} \\
& [001] \mathrm{Fe} / /[\overline{1} 10] \mathrm{Au}\}
\end{aligned}
$$

(2) 濃塩酸の添加は素地鉄面上の酸化皮膜層などを破 壊除去し, 素地面の清浄化に有効であった。

(3) 塩酸添加量が増加した浴, すなわちより低 $\mathrm{pH}$ 浴 からの初期析出金膜汪ど単結晶性は向上しており，乙か も膜の連続性といら点でもすぐれたものが得られた。

(4) 塩酸添加により金膜の成長速度が増加した。 （1972-3-23 受理）

(昭和 45 年 5 月, 本協会第 41 回学術講演大会にて一部発 表)

\section{文献}

1）田辺良美, 釜崎清治, 本誌, 21，280（1970）

2) 田辺良美, 釜崎清治, 本誌, 22, 54 (1971)

3) B. W. Sloope and C. O. Tiller, J. Appl. Phys., 32, 1331 (1961)

4 ) S. Ino, D. Watanabe and S. Ogawa, J. Phys. Soc. Japan, 19, 881 (1964) 